\title{
KONSUMSI MINUMAN DAN PREFERENSINYA PADA REMAJA DI JAKARTA DAN BANDUNG
}

\author{
Dodik Briawan'; Hardinsyah; Marhamah²; Zulaikhah³; dan M. Aries ${ }^{4}$ \\ ${ }^{1}$ Staf pengajar pada Dept. Gizi Masyarakat, FEMA, IPB \\ ${ }^{2}$ Asisten peneliti di Fakultas Ekologi Manusia, IPB \\ ${ }^{3}$ Asisten peneliti pada SEAFAST Center, IPB \\ ${ }^{4}$ Asisten dosen, Dept Gizi Masyarakat, FEMA, IPB
}

\section{ABSTRAK}

Studi ini adalah cross-sectional yang dilakukan di Jakarta (pantai) dan di Bandung (pegunungan) dengan suhu rata-rata harian masing masing adalah $28^{\circ} \mathrm{C}$ dan $22^{\circ} \mathrm{C}$. Sampel dipilih secara acak dari sekolah berturut-turut sebanyak masing masing 110 orang dan 99 orang. Data dikumpulkan melalui pengisian kuesioner, dan recall selama satu minggu untuk konsumsi aneka jenis minuman. Sebagian besar $(73,2 \%)$ remaja di Bandung lebih menyukai air minum tanpa kemasan. Namun kebiasaan tersebut berbeda untuk di Jakarta, yaitu proporsi remaja yang mengkonsumsi air minum tanpa kemasan relatif sama dengan air kemasan ( $52,3 \%$ dan $47,7 \%)$. Rata-rata konsumsi air minum tanpa kemasan per hari secara signifikan lebih rendah di Jakarta $(934 \mathrm{~mL})$ daripada di Bandung $(1038 \mathrm{~mL})(p<0,05)$, sedangkan air minum kemasan secara signifikan berbeda, yaitu berturut-turut $1138 \mathrm{~mL}$ dan $452 \mathrm{~mL}(p<0,05)$. Remaja di pantai mengonsumsi air minum 500-600 ml lebih banyak dibandingkan di pegunungan. Lebih dari 16 kelompok minuman lainnya yang terdiri dari berbagai jenis minuman yang dikonsumsi oleh remaja, sehingga total asupan minuman per hari secara signifikan lebih besar di Jakarta $(2787 \mathrm{~mL})$ daripada di Bandung $(2196$ $\mathrm{mL})(p<0,05)$. Meskipun asupan air minum (plain water) remaja di pegunungan hanya sekitar $1500 \mathrm{~mL}$, namun rata-rata total asupan cairan di kedua daerah sudah lebih tinggi jika dibandingkan dengan anjuran minum air (PUGS) sebanyak 2 liter.

Kata kunci: konsumsi minuman, preferensi minuman, asupan cairan, remaja

\section{ABSTRACT}

\section{THE CONSUMPTION OF BEVERAGES AND ITS PREFERENCE AMONG ADOLESCENTS LIVING IN JAKARTA AND BANDUNG}

The objective of the study is to analyze the beverages preference and consumption of adolescents living in two different climates. The cross-sectional study was applied to 110 and 99 of high school students in Northern Jakarta and West Bandung to represent a coastal and mountainous areas respectively. A one week recall was applied to assess estimation of water intakes. The water intake was a summation of various beverages including drinking water.The results showed that the adolescents in Bandung prefered to drink home prepared water which the proportion was higher (73.2\%) than those in Jakarta (52.3\%). However, the adolescents in the coast mostly drank more bottled-water 3.9 times/day compared to 1.8 times/day in the mountainous area. The average of water intake was significantly higher in the coast $(2787 \pm 1267 \mathrm{ml})$ compared to the mountain areas $(2195 \pm 893 \mathrm{ml})$. The contribution of total drinking water was $74.3 \%$ dan $67.9 \%$ respectively.

Key words: beverage consumption , beverage preference, water intake, adolescent

\section{PENDAHULUAN}

A ir merupakan senyawa esensial yang keberadaannya sangat diperlukan untuk proses kehidupan. Tubuh manusia terdiri dari 55-75 persen air. Kondisi keseimbangan cairan dalam tubuh yang negatif atau biasa disebut dehidrasi (penurunan penurunan cairan 2-6\%). Dehidrasi disebabkan karena penurunan asupan air, peningkatan pengeluaran air (melalui ginjal, saluran pencernaan dan lainnya), ataupun perubahan cairan. Penurunan terhadap total cairan dalam tubuh akan menyebabkan terjadinya penurunan volume cairan intraseluler maupun ekstraseluler. Perwujudan klinis dari dehidrasi kebanyakan dikaitkan dengan penurunan volume intravaskular yang akan menyebabkan terjadinya kegagalan fungsi organ dan akhirnya kematian. ${ }^{1}$ 
Meskipun fungsi air sangat penting, tetapi sering terabaikan dalam kebiasaan pola makan keseharian. Tidak semua orang dapat mencukupi untuk kebutuhan cairan tubuhnya. Misalnya, studi di Singapura yang menunjukkan wanita minum air 5-6 gelas dan pria minum 6-8 gelas dalam sehari. Kebiasaan minum tersebut lebih rendah dari pada rekomendasi minum dalam sehari sebanyak 8 gelas. Pada studi tersebut hanya kelompok usia tua (55-64 tahun) dan dewasa muda (25-34 tahun) yang sudah memenuhi anjuran minum air. ${ }^{2}$ Studi di Hongkong menunjukkan hasil yang sama bahwa 50\% sampel minum air kurang dari 8 gelas, dan bahkan 30 persen diantaranya minum kurang dari 5 gelas dalam satu hari. ${ }^{2}$

Terdapat berbagai alasan kebutuhan cairan tubuh tidak tercukupi, antara lain karena: 1) tidak haus, 2) lupa minum, 3) merepotkan, dan 4) tidak mau sering ke kamar kecil. Sebanyak 70 persen sampel baru minum setelah merasa haus, dan sebenarnya ini sudah terlambat karena haus merupakan indikasi awal dari dehidrasi. ${ }^{2}$ Sementara itu studi Grandjean AC et al $(2003)^{3}$ menyebutkan bahwa konsumsi minuman harus cukup, terutama saat musim panas agar terhindar dari dehidrasi.

Kebutuhan air tubuh tergantung dari keseimbangan cairan yang ditentukan antara air yang diperoleh dan keluar dari tubuh. Tubuh memperoleh air dari konsumsi (makanan dan minuman) dan hasil metabolisme, sedangkan air keluar melalui pernafasan, kulit, ginjal, dan saluran perncernaan. Estimasi total kehilangan air dari butuh pada orang dewasa dengan aktivitas ringan sebesar $1050-3100 \mathrm{ml}$ per hari. ${ }^{4}$ Survey pada populasi dewasa di USA menunjukkan total asupan air 28 persen berasal dari makanan, 28 persen air putih, dan 44 persen dari minuman lainnya. Asupan air seseorang akan tergantung dari tingkat aktivitas, lingkungan, pola makan, dan aktivitas sosialnya.

Studi di berbagai negara menunjukkan terdapat variasi kontribusi aneka minuman terhadap asupan cairan tubuh. Kandungan air dari berbagai jenis minuman diperkirakan untuk teh dan kopi 9,5 persen, minuman olah raga 95 persen, jus 90-94 persen, dan susu (whole milk) 87 persen. $^{5}$ Institute of Medicine (2004) menganalisis data NHANES III, hasilnya menunjukkan rata-rata asupan total air (makanan dan minuman) pada remaja (14-18 tahun) laki-laki sebesar 3,4 L/hari dan perempuan 2,5 L/hari. Pada kelompok dewasa (31-50 tahun) pria, total konsumsi air sebesar 3,85 L/hari dan wanita 3,10 L/hari. Perbedaan asupan air antara kelompok yang secara fisik aktif dan tidak aktif pada laki-laki $0,6 \mathrm{~L}$ dan untuk wanita $0,5 \mathrm{~L}$. Asupan air tersebut lebih rendah dibandingkan di Kanada, yaitu untuk dewasa pria 2,96 L/hari dan wanita 2,55 L/hari. ${ }^{4}$

Secara umum Departemen Kesehatan Indonesia $(2005)^{6}$ merekomendasikan cairan, terutama air minum, yang harus dikonsumsi untuk orang dewasa adalah dua liter atau setara delapan gelas setiap hari. Kehilangan air tubuh yang tidak kentara (insesible) melalui paru-paru dan kulit kurang lebih separuh dari total air turnover. Selebihnya kehilangan cairan tubuh melalui urine dan feses. Kehilangan air tubuh ini (insensible) sangat sensitif terhadap perubahan lingkungan, seperti suhu udara yang tinggi, kelembaban udara rendah, dan ketinggian tempat tinggal. ${ }^{7}$

Sampai saat ini belum banyak studi di Indonesia tentang kebiasaan minum pada kelompok remaja. Studi ini secara umum mengkaji preferensi dan konsumsi minuman pada remaja di Jakarta dan Bandung sebagai representasi wilayah pantai dan pegunungan. Tujuan khusus studi adalah: 1) mengkaji jenis dan kesukaan konsumsi minuman pada remaja, 2) membandingkan jenis dan frekuensi konsumsi aneka minuman, dan 3) menghitung asupan cairan dari aneka minuman di wilayah yang berbeda.

\section{METODE PENELITIAN}

Studi ini merupakan bagian dari multi-site study "Studi kebiasaan minum dan status dehidrasi remaja dan dewasa di dua wilayah ekologi yang berbeda" yang dilakukan oleh FEMA-IPB tahun 2008. Desain studi adalah cross-sectional dengan lokasi yang ditetapkan secara purposif berdasarkan ketinggian daerah tempat tinggal. Pada pembahasan ini, analisis data khusus untuk lokasi di Jakarta dan Bandung, yang berturut-turut mewakili daerah dataran rendah dan tinggi. Daerah dengan ketinggian 700-1050 $\mathrm{m}$ dpl (di atas permukaaan laut) di Lembang dan 5-50 m dpl di Jakarta Utara, dengan suhu rata-rata harian berturutturut $28^{\circ} \mathrm{C}$ dan $22^{\circ} \mathrm{C}$. 
Sampel studi adalah remaja laki-laki dan perempuan, usia 15-18 tahun, masih bersekolah, kondisi sehat atau tidak sedang menderita penyakit kronis/akut. Sampel di pilih secara acak dari SMA di kedua wilayah terpilih yang bersedia menjadi tempat penelitian. Untuk itu terpilih sebanyak 99 orang dari SMA I Lembang dan SMA Ciparongpong (wilayah pegunungan); dan sebanyak 110 orang di SMA 92 dan SMA 45 Jakarta Utara (wilayah pantai).

Data dikumpulkan pada bulan OktoberNovember 2008. Data karakteristik sampel dan kebiasaan minum dikumpulkan melalui pengisian kuesioner oleh sampel yang didampingi oleh tenaga lapangan yang sebelumnya telah dilatih. Data asupan aneka jenis minuman dikumpulkan melalui kombinasi pencatatan sendiri dan recall selama satu minggu sebelumnya. Analisis dilakukan secara deskriptif untuk menggambarkan kebiasaan minum remaja antar wilayah pantai dan pegunungan. Analisis statistik (t-tes) digunakan untuk menganalisis perbedaan asupan minuman antar daerah pantai dan pegunungan.

\section{HASIL}

\section{Karakteristik Remaja dan Keluarganya}

Dari jumlah sampel 110 di Jakarta dan 99 di Bandung, proporsi jumlah laki-laki terhadap perempuan berturut-turut sebesar 54,1 persen dan 48,5 persen. Rata-rata umur remaja di kedua wilayah hampir sama, yaitu 16,0 $\pm 1,0$ tahun (Jakarta) dan 15,9 $\pm 1,0$ (Bandung). Remaja dengan kategori kurus (IMT< 18,5 $\mathrm{kg} / \mathrm{m}^{2}$ ) sebanyak 29,4 persen di wilayah pantai dan 25,8 persen di wilayah pegunungan, dan rata-rata IMT seluruh remaja adalah $21,4 \mathrm{~kg} / \mathrm{m}^{2}$ (Jakarta) dan 20,0 kg/m² (Bandung). Uang saku remaja berturut-turut sebesar Rp 76.330 dan Rp 62.989 per minggu.

Sampel remaja berasal dari keluarga dengan latar belakang ekonomi tingkat sedang, yaitu keluarga dengan pendapatan per bulan kurang dari 1 juta sebesar 29,4 persen (Jakarta) dan 26,8 persen (Bandung), dan yang mempunyai pendapatan 1-2 juta berturut-turut sebesar 33,9 persen dan 49,5 persen. Belanja keluarga untuk pembelian air minum sebesar Rp. 98 394/bulan (Jakarta) dan Rp 32.551/bulan (Bandung).
Terdapat perbedaan pola penggunaan sumber air minum untuk keluarga antara kedua wilayah. Keluarga remaja di Jakarta hampir sebagian besar $(74,3 \%)$ menggunakan air galon, dan 32,1 persen air ledeng. Untuk keluarga di Bandung sumber air minum yang digunakan lebih beragam, yaitu air galon 38,1 persen, mata air 27,8 persen, air ledeng 26,8 persen, air sumur 20,6 persen, dan lainnya 2,1 persen. Dari keluarga pengguna air galon tersebut, jenis air galon dengan kategori isi ulang (refill) hanya pada sebagian kecil sampel, yaitu pada 33,0 persen (Jakarta) dan 30,9 persen (Bandung).

\section{Kesukaan Jenis Minuman pada Remaja}

Berdasarkan kebiasaan penggunaan jenis air minum kemasan dan tanpa kemasan, sebagian besar remaja lebih menyukai air minum tanpa kemasan, yaitu 73,2 persen di Jakarta dan 52,3 persen di Bandung. Apabila dibandingkan kesukaan terhadap air putih (plain water) dengan jenis minuman lainnya, maka hanya 39,4 persen remaja di wilayah pantai dan 52,6 persen di wilayah pegunungan yang menyukai minuman lainnya (selain air putih). Alasan remaja yang menyukai minuman lainnya kebanyakan adalah karena pertimbangan rasa, yaitu 69,8 persen di pantai dan 98,2 persen di pegunungan. Jenis dan alasan minuman yang disukai remaja di kedua wilayah disajikan pada Tabel 1.

Masing-masing sampel diminta untuk menyebutkan tiga jenis minuman selain air putih yang disukai. Terdapat 16 jenis minuman yang disebutkan oleh remaja, dengan distribusi yang hampir sama di antara kedua lokasi studi. Untuk remaja di wilayah pantai (Jakarta), kebanyakan minuman yang disukai adalah teh kemasan $(13,8 \%)$, minuman elektrolit $(14,7 \%)$, teh seduh di rumah (12,8\%), dan selebihnya berupa aneka minuman lainnya. Untuk remaja di wilayah pegunungan (Bandung), distribusi preferensi terhadap minuman tersebut yang relatif lebih banyak adalah teh kemasan $(26,8 \%)$, teh/ kopi seduh yang disiapkan di rumah $(23,7 \%)$, susu sapi segar $(17,5 \%)$, minuman serbuk aneka rasa $(14,4 \%)$, minuman elektrolit $(14,4 \%)$ dan selebihnya berbagai jenis minuman lainnya. Pada kedua lokasi tampaknya jenis minuman teh dan kopi yang paling diminati oleh remaja. 
Tabel 1

Persentasi Remaja Berdasarkan Jenis dan Alasan Minuman yang Disukai di Jakarta dan Bandung

\begin{tabular}{lrrr}
\hline \multicolumn{1}{c}{ Jenis minuman } & Jakarta & Bandung & Rataan \\
\hline Jenis minuman: & & & \\
Air putih tanpa kemasan & 52,3 & 73,2 & 62,1 \\
Minuman lainnya & 39,4 & 52,6 & 45,6 \\
\hline Alasan minum: & & & \\
Air minum tanpa kemasan & & & \\
a. Rasa & 12,1 & 8,5 & 10,1 \\
b. Keamanan & 81,0 & 80,3 & 80,6 \\
c. Harga & 1,7 & 2,8 & 2,3 \\
d. Kemudahan & 5,2 & 7,0 & 6,2 \\
e. Lainnya & 0,0 & 1,4 & 0,8 \\
\hline Air minum kemasan & 100,0 & 100,0 & 100,0 \\
a. Rasa & 7,7 & 9,6 & 9,0 \\
b. Keamanan & 80,8 & 65,4 & 70,5 \\
c. Kemudahan & 11,5 & 23,1 & 19,2 \\
d. Lainnya & 0,0 & 1,9 & 1,3 \\
\hline Minuman lainnya & & & \\
a. Rasa & 69,8 & 98,2 & 85,1 \\
b. Keamanan & 14,0 & 0,0 & 6,4 \\
c. Harga & 2,3 & 0,0 & 1,1 \\
d. Kemudahan & 7,0 & 0,0 & 3,2 \\
e. Lainnya & 2,3 & 2,0 & 4,3 \\
\hline
\end{tabular}

\section{Jenis dan Frekuensi Minuman Remaja}

Kebiasaan minum remaja dilihat berdasarkan recall satu minggu sebelumnya. Terdapat perbedaan frekuensi air minum antara remaja di wilayah pantai dan pegunungan. Sebagai sumber cairan tubuh pada remaja, terutama cairan berasal dari air minum (plain water). Kelompok aneka minuman tersebut dibedakan antara yang kemasan (mempunyai merek) dan tanpa kemasan (tanpa merek). Frekuensi jenis minuman remaja disajikan pada Tabel 2.

Rata-rata frekuensi air minum tanpa kemasan di Jakarta 24,6 kali/minggu (3,5 kali/hari) dan air kemasan 26,9 kali/minggu (3,9 kali/hari), sedangkan di Bandung air minum tanpa kemasan 32,2 kali/minggu (4,6 kali/hari) dan air kemasan 12,3 kali/minggu (1,8 kali/hari).
Remaja di wilayah pegunungan minum air putih tanpa kemasan secara signifikan lebih sering dibandingkan di wilayah pantai, dan sebaliknya remaja di wilayah pantai minum air kemasan lebih banyak dibandingkan di wilayah pegunungan $(p<0,05)$. Proporsi jumlah remaja yang mengkonsumsi air minum tanpa kemasan sebanyak 86 persen di wilayah pegunungan dan 66 persen di wilayah pantai. Sebaliknya jumlah remaja yang mengkonsumsi air minum kemasan di wilayah pantai lebih tinggi (95\%) dibandingkan di wilayah pegunungan (85\%).

Jenis minuman urutan kedua yang paling banyak dikonsumsi remaja di kedua wilayah adalah teh dan kopi. Frekuensi konsumsi teh dan kopi berbeda secara signifikan antara remaja di Jakarta (pantai) rata-rata 10,3 kali/minggu (1,5 kali/hari) dan di Bandung 
(pegunungan) 11,5 kali/minggu (1,6 kali/hari) $(p<0,05)$. Jumlah remaja yang mengkonsumsi teh dan kopi berturut-turut 79 persen dan 84 persen.

Tabel 2

Rata-rata frekuensi minum menurut jenis minuman oleh remaja di Jakarta dan Bandung

\begin{tabular}{|c|c|c|c|c|c|c|}
\hline \multirow[t]{2}{*}{ Jenis Minuman } & \multicolumn{2}{|c|}{$\begin{array}{c}\text { Jakarta } \\
\text { (kali/minggu) }\end{array}$} & \multicolumn{2}{|c|}{$\begin{array}{c}\text { Bandung } \\
\text { (kali/minggu) }\end{array}$} & \multicolumn{2}{|c|}{$\begin{array}{c}\text { Rataan } \\
\text { (kali/minggu) }\end{array}$} \\
\hline & $\mathbf{x}$ & $\pm s d$ & $x$ & $\pm s d$ & $x$ & $\pm s d$ \\
\hline Air putih tanpa kemasan ${ }^{*}$ & 24,6 & $\pm 23,4$ & 32,2 & $\pm 14,8$ & 28,4 & $\pm 19,1$ \\
\hline Air putih kemasan* & 26,9 & $\pm 21,3$ & 12,3 & $\pm 15,4$ & 19,6 & $\pm 18,4$ \\
\hline Jus/sari buah tanpa kemasan & 1,3 & $\pm 1,5$ & 1,5 & $\pm 1,4$ & 1,4 & $\pm 1,5$ \\
\hline Sari buah kemasan & 0,9 & $\pm 1,8$ & 0,7 & $\pm 1,5$ & 0,8 & $\pm 1,7$ \\
\hline Aneka es buah/campur/kelapa & 4,8 & $\pm 1,2$ & 4,9 & $\pm 1,6$ & 4,9 & $\pm 1,4$ \\
\hline Minuman serbuk ${ }^{*}$ & 6,3 & $\pm 3,4$ & 2,9 & $\pm 1,6$ & 4,6 & $\pm 2,5$ \\
\hline Minuman jelly* & 0,5 & $\pm 1,3$ & 1,2 & $\pm 1,5$ & 0,9 & $\pm 1,4$ \\
\hline Susu tanpa kemasan* & 0,3 & $\pm 6,2$ & 2,0 & $\pm 4,2$ & 1,2 & $\pm 5,2$ \\
\hline Susu dan yoghurt kemasan* & 8,3 & $\pm 4,6$ & 5,5 & $\pm 4,8$ & 6,9 & $\pm 4,7$ \\
\hline Teh dan kopi tanpa kemasan & 10,3 & $\pm 5,4$ & 11,4 & $\pm 4,4$ & 10,9 & $\pm 4,9$ \\
\hline Minuman karbonasi & 1,4 & $\pm 2,9$ & 1,8 & $\pm 1,6$ & 1,6 & $\pm 2,3$ \\
\hline Bir dan minuman beralkohol & 0,1 & $\pm 2,1$ & 0,1 & $\pm 1,0$ & 0,1 & $\pm 1,6$ \\
\hline Jamu dan minuman herbal & 0,4 & $\pm 5,6$ & 0,3 & $\pm 2,7$ & 0,4 & $\pm 4,2$ \\
\hline Minuman lainnya & 0,6 & $\pm 1,7$ & 1,0 & $\pm 2,8$ & 0,8 & $\pm 2,3$ \\
\hline Minuman elektrolit & 0,6 & $\pm 1,4$ & 0,4 & $\pm 1,2$ & 0,5 & $\pm 1,3$ \\
\hline
\end{tabular}

*signifikan $p<0,05$

\section{Jumlah Konsumsi Minuman Remaja}

Pada remaja di kedua wilayah yang berbeda, total asupan cairan per hari dari aneka jenis minuman lebih tinggi di Jakarta $(2787 \mathrm{ml})$ dibandingkan dengan di Bandung (2196 ml) $(p<0,05)$. Kontribusi terbesar asupan cairan tersebut berasal dari air minum lebih besar di wilayah pantai $(2072 \mathrm{ml}$ atau $74,3 \%)$ dibandingkan dengan wilayah pegunungan (1490 $\mathrm{ml}$ atau $67,9 \%)$. Rata-rata asupan cairan dari aneka jenis minuman disajikan pada Tabel 3.

Asupan air minum oleh remaja di Bandung rata-rata sebanyak $1489 \mathrm{ml}$, lebih rendah dibandingkan dengan Jakarta $2072 \mathrm{ml}$ per hari $(P>0,05)$. Berdasarkan kontribusi jenis air minum, pola asupan air minum remaja di kedua wilayah tidak berbeda nyata $(p>0,05)$, yaitu di wilayah pantai sebagian besar berasal dari air kemasan $(1138 \mathrm{ml})$, dan di wilayah pegunungan berasal dari air minum tanpa kemasan (1038 $\mathrm{ml})$.

Remaja termasuk biasa dalam mengkonsumsi minuman teh/kopi. Rata-rata teh/ kopi per hari yang disiapkan di rumah dikonsumsi sebanyak $140 \mathrm{ml}$ di Jakarta dan 134 $\mathrm{ml}$ di Bandung $(p>0,05)$. Namun konsumsi minuman karbonasi ternyata tidak banyak, berturut-turut hanya $50 \mathrm{ml}$ dan $60 \mathrm{ml}$ per hari dan tidak berbeda secara signifikan antar kedua wilayah $(p>0,05)$.

Kontribusi asupan cairan yang berasal dari susu dan yogurt cukup signifikan (5,3\%), yaitu rata-rata per hari sebesar $156 \mathrm{ml}$ di pantai dan $109 \mathrm{ml}$ di pegunungan $(p<0,05)$. Asupan susu/yogurt tersebut jumlah sekitar 50 persen dibandingkan dari asupan negara maju. 
Tabel 3

Rata-rata asupan cairan dari berbagai jenis minuman oleh remaja di Jakarta dan Bandung

\begin{tabular}{|c|c|c|c|c|c|c|}
\hline \multirow[t]{2}{*}{ Jenis Minuman } & \multicolumn{2}{|c|}{$\begin{array}{l}\text { Jakarta } \\
\text { (ml/hari) }\end{array}$} & \multicolumn{2}{|c|}{ Bandung (ml/hari) } & \multicolumn{2}{|c|}{$\begin{array}{l}\text { Rataan } \\
\text { (ml/hari) }\end{array}$} \\
\hline & $\mathrm{x}$ & $\pm s d$ & $\mathrm{x}$ & $\pm s d$ & $x$ & $\pm s d$ \\
\hline Air putih tanpa kemasan & 934,3 & $\pm 894,0$ & 1038,4 & $\pm 491,3$ & 986,4 & $\pm 692,7$ \\
\hline Air putih kemasan* & 1138,0 & $\pm 773,0$ & 451,9 & $\pm 512,3$ & 795,0 & $\pm 642,7$ \\
\hline Jus/sari buah tanpa kemasan & 51,3 & $\pm 58,3$ & 58,1 & $\pm 56,1$ & 54,7 & $\pm 57,2$ \\
\hline Sari buah kemasan & 30,7 & $\pm 66,7$ & 23,5 & $\pm 45,9$ & 27,1 & $\pm 56,3$ \\
\hline Es buah/campur/kelapa & 55,0 & $\pm 43,6$ & 48,2 & $\pm 43,8$ & 51,6 & $\pm 43,7$ \\
\hline Minuman serbuk ${ }^{*}$ & 102,9 & $\pm 97,0$ & 49,1 & $\pm 56,9$ & 76,0 & $\pm 77,0$ \\
\hline Minuman jelly ${ }^{*}$ & 15,2 & $\pm 37,3$ & 30,0 & $\pm 39,5$ & 22,6 & $\pm 38,4$ \\
\hline Susu tanpa kemasan* & 8,6 & $\pm 178,9$ & 66,5 & $\pm 127,0$ & 37,6 & $\pm 153,0$ \\
\hline Susu \& yoghurt kemasan* & 155,5 & $\pm 132,7$ & 109,2 & $\pm 134,5$ & 132,4 & $\pm 133,6$ \\
\hline Teh \& kopi tanpa kemasan & 140,0 & $\pm 173,2$ & 133,5 & $\pm 106,5$ & 136,8 & $\pm 139,9$ \\
\hline Teh \& kopi dalam kemasan* & 40,4 & $\pm 53,3$ & 66,5 & $\pm 81,8$ & 53,5 & $\pm 67,6$ \\
\hline Minuman karbonasi & 50,8 & $\pm 95,0$ & 59,7 & $\pm 45,4$ & 55,3 & $\pm 70,2$ \\
\hline Bir \& minuman beralkohol & 2,5 & $\pm 89,0$ & 5,9 & $\pm 98,5$ & 4,2 & $\pm 93,8$ \\
\hline Jamu \& minuman herbal & 12,2 & $\pm 201,1$ & 6,5 & $\pm 62,1$ & 9,4 & $\pm 131,6$ \\
\hline Minuman lainnya & 19,9 & $\pm 65,5$ & 26,0 & $\pm 88,2$ & 23,0 & $\pm 76,9$ \\
\hline Minuman elektrolit & 29,9 & $\pm 65,7$ & 22,8 & \pm 82.9 & 26.4 & $\pm 74,3$ \\
\hline Rata-rata* & 2787,0 & $\pm 492,8$ & 2195,6 & $\pm 338,8$ & 2491,3 & $\pm 415,8$ \\
\hline
\end{tabular}

*signifikan $p<0,05$

\section{BAHASAN}

Berdasarkan karakterisik individu tidak terdapat berbedaan umur, ukuran antropometri, dan sosial ekonomi keluarga antara kedua kelompok remaja di kedua wilayah. Namun pengeluaran untuk keperluan air minum keluarga tiga kali lebih tinggi wilayah pantai (Jakarta) dibandingkan di wilayah pegunungan (Bandung). Di Jakarta hampir semua keluarga $(74,3 \%)$ membeli air (air galon) untuk keperluan memasak, termasuk air minum karena air PAM dan air tanah dianggap tidak layak. Sedangkan di Bandung, hanya sebagian kecil keluarga yang membeli air minum dan selebihnya menggunakan air sumur. Rata-rata jumlah air galon yang digunakan terbanyak pada wilayah pantai (7,8 galon/bulan), sedangkan di wilayah pegunungan hanya 2,3 galon/bulan.

Seperti halnya dalam konsumsi jenis makanan, maka kebiasaan minum akan berbeda-beda antar kelompok usia, jenis kelamin, dan antar wilayah. Terdapat perbedaan kebiasaan minum pada remaja tersebut ditemukan di wilayah pantai dan pegunungan. Preferensi minum remaja adalah air minum (plain water) tanpa kemasan dibandingkan yang kemasan. Ketersediaan sumber air bersih yang melimpah di wilayah pegunungan membuat mereka lebih menyukai air minum tanpa kemasan. Namun untuk remaja di wilayah pantai, yang menyukai air minum tanpa kemasan relatif sama dengan yang menyukai air minum kemasan (berturut-turut $52,3 \%$ dan $39,4 \%$ ). Hal tersebut terjadi karena kualitas air bersih di wilayah pantai utara Jakarta dianggap kurang baik, sehingga sebagian remaja tidak memilih air minum yang berasal dari rumah tangga (tanpa kemasan).

Alasan lebih menyukai air putih tanpa kemasan pada kedua kelompok remaja adalah karena pertimbangan keamanannya, yaitu 81,0 persen dan 80,3 persen. Demikian pula alasan bagi mereka yang menyukai air minum kemasan adalah karena keamanannya, yaitu berturut-turut 65,4 persen dan 80,8 persen. Selain itu pertimbangan berikutnya dari memilih air minum kemasan adalah kemudahan. Data tersebut menunjukkan terdapat perhatian yang sama pada kedua lokasi studi terhadap isu keamanan air minum untuk kebutuhan seharihari. Meskipun persepsi air minum yang aman antara air kemasan dan non-kemasan berbedabeda antara remaja. Depkes $(2005)^{6}$ 
mensyaratkan bahwa air minum harus bersih dan aman, dan untuk mendapatkannya air minum harus terlebih dahulu direbus sampai mendidih.

Apabila dibandingkan kesukaan terhadap air puth (plain water) dengan jenis minuman lainnya, maka hanya 39,4 persen remaja di wilayah pantai dan 52,6 persen di wilayah pegunungan yang menyukai minuman selain air putih. Cuaca panas di pantai kemungkinan menyebabkan lebih banyak remaja yang lebih suka terhadap air putih dibandingkan minuman lainnya. Adapun alasan bagi mereka yang menyukai minuman lainnya (selain air putih) kebanyakan adalah karena pertimbangan rasa. Remaja akan minum selain air putih, dengan harapan akan memperoleh nilai lebih yaitu dalam hal rasa dibandingkan alasan-alasan lainnya. Selain aspek rasa minuman, remaja di wilayah pantai yang menyatakan memilih minum lainnya karena alasan keamanan. Terdapat 16 jenis minuman yang disebutkan oleh remaja, dengan distribusi yang hampir sama diantara kedua lokasi studi. Minuman yang paling banyak dikonsumsi adalah air minum, dan yang paling sedikit adalah minuman beralkohol (3-5\%); sedangkan susu tidak banyak diminum oleh remaja di kedua lokasi.

Rata-rata frekuensi air minum tanpa kemasan di wilayah pantai 3,5 kali/hari dan air kemasan 3,9 kali/hari, sedangkan di wilayah pegunungan air minum tanpa kemasan 4,6 kali/ hari dan air kemasan 1,8 kali/hari. Remaja di pegunungan minum air putih tanpa kemasan secara signifikan lebih sering dibandingkan di pantai, dan sebaliknya remaja di pantai minum air kemasan lebih banyak dibandingkan di pegunungan $(p<0,05)$. Remaja di wilayah pegunungan jarang mengonsumsi air kemasan dibandingkan dengan di pantai kemungkinan karena uang saku lebih rendah dan ketersediaan sumber air minum yang masih relatif baik di wilayah pegunungan. Jika dibandingkan dengan data NHANES di USA, dari total konsumsi air kontribusi terbesar berasal dari minuman (beverages) 49-63 persen, air minum (putih) 35-54 persen, dan makanan padat $19-25$ persen. ${ }^{4}$

Jenis minuman urutan kedua yang paling banyak dikonsumsi remaja di kedua wilayah adalah teh dan kopi. Frekuensi konsumsi teh dan kopi berbeda secara signifikan antara remaja di pantai rata-rata 10,3 kali/minggu (1,5 kali/hari) dan di pegunungan $11,5 \mathrm{kali} /$ minggu $(1,6$ kali/hari) $(p<0,05)$. Jumlah sampel yang mengkonsumsi teh dan kopi berturut-turut 79 persen dan 84 persen. Survey di Singapura menunjukkan sumber cairan tubuh adalah air putih menempati urutan pertama (74\%). Minuman teh dan kopi urutan kedua 32 persen, minuman ringan 17 persen. Sebagai sumber cairan lainnya adalah dari buah dan salad. ${ }^{2}$

Setelah air putih, teh, dan kopi, berikutnya adalah susu dan yogurt merupakan minuman yang sering dikonsumsi oleh remaja di wilayah pantai. Minuman tersebut dikonsumsi oleh 60 70 persen sampel, rata-rata frekuensi adalah 8,4 kali/minggu di pantai dan $5,5 \mathrm{kali} / \mathrm{ming} g \mathrm{u}$ di pegunungan $(p<0,05)$. Didalam PUGS tidak terdapat rekomendasi remaja untuk minum susu (Depkes 2005). Survey di US menunjukkan asupan cairan (fluid) ke dalam tubuh sebesar $1764 \mathrm{ml}$ per hari, dengan rincian air putih 673 $\mathrm{ml}$, susu $312 \mathrm{ml}$, teh dan kopi $360 \mathrm{ml}$, dan minuman ringan $420 \mathrm{ml}$ per hari. ${ }^{7}$

Minuman berkarbonasi dikonsumsi oleh 67 persen remaja di pegunungan dan 48 persen di pantai. Namun kalau dilihat dari frekuensinya, minuman tersebut hanya dikonsumsi 1,8 kali/minggu di pegunungan dan $1,4 \mathrm{kali} / \mathrm{minggu}$ di pantai $(p<0,05)$. Jika dibandingkan dengan data di USA, maka konsumsi minuman berkarbonasi jauh lebih tinggi dibandingkan dengan air minum.

Es buah/campur merupakan alternatif minuman lokal yang menjadi pilihan remaja. Sebanyak 65 persen remaja di wilayah pantai dan 60 persen di wilayah pegunungan mengonsumsi es tersebut dengan frekuensi berturut-turut sebesar 4,8 dan 4,9 kali/minggu $(p>0,05)$. Es buah/campur dijumpai dengan mudah hampir di setiap sekolah di lokasi studi. Untuk jenis minuman lainnya tidak banyak dikonsumsi oleh remaja, dan frekuensi konsumsinya juga relatif jarang, misalnya minuman jus, minuman elektrolit, jamu, jelly, sari buah sangat kecil, yaitu kurang dari 1-2 kali/minggu.

Tubuh manusia dalam jumlah yang terbatas dapat memproduksi air melalui proses oksidasi. Namun demikian jumlahnya masih lebih rendah dibandingkan dari makanan padat terutama sayuran dan buah, yang memberikan kontribusi nyata terhadap asupan cairan. Studi pada kelompok dewasa pria dengan berat 70 $\mathrm{kg}$, dengan asupan energi $2900 \mathrm{kkal}$, makanan 
padat menyumbang air sebesar $1000 \mathrm{ml}$ per hari. Jika produksi air dalam tubuh sebesar 250 $\mathrm{ml}$, maka selebihnya kebutuhan air harus dipenuhi dari minuman. ${ }^{4}$

Pada remaja di kedua wilayah yang berbeda, total asupan cairan per hari dari aneka jenis minuman lebih tinggi di wilayah pantai (2 $787 \mathrm{ml}$ ) dibandingkan dengan di wilayah pegunungan $(2196 \mathrm{ml}) \quad(p<0,05)$. Kontribusi terbesar asupan cairan tersebut berasal dari air minum lebih besar di wilayah pantai $(2072 \mathrm{ml}$ atau $74,3 \%$ ) dibandingkan dengan wilayah pegunungan (1 $490 \mathrm{ml}$ atau $67,9 \%$ ). Rata-rata kontribusi air minum di pantai tersebut kurang lebih sama dengan hasil survei di Singapura sebesar 74 persen (AFIC 2002). Studi di Bogor pada siswa SMA menunjukkan asupan cairan pada laki-laki $(2939 \mathrm{ml})$ lebih banyak dibandingkan perempuan $(2250 \mathrm{ml})$, sedangkan kontribusi air minum berturut-turut sebesar 1495 $\mathrm{ml}$ dan $1312 \mathrm{ml}^{8}$

Asupan air minum oleh remaja di wilayah pegunungan rata-rata sebanyak $1489 \mathrm{ml}$, lebih rendah dibandingkan dengan wilayah pantai $2072 \mathrm{ml}$ per hari $(P>0,05)$. Asupan air minum untuk wilayah pegunungan lebih rendah dari rekomendasi minum air putih sebesar $2000 \mathrm{ml}$ (Depkes, 2005). Kontribusi air minum tanpa kemasan pada remaja di kedua wilayah tidak berbeda, baik di wilayah pantai maupun di wilayah pegunungan (1038 ml).

Remaja termasuk biasa dalam mengonsumsi minuman teh/kopi. Rata-rata teh/kopi per hari yang disiapkan di rumah dikonsumsi sebanyak $140 \mathrm{ml}$ di wilayah pantai dan $134 \mathrm{ml}$ di wilayah pegunungan $(p>0,05)$. Namun konsumsi minuman karbonasi ternyata tidak banyak, berturut-turut hanya $50 \mathrm{ml}$ dan 60 $\mathrm{ml}$ per hari dan tidak berbeda secara signifikan antar kedua wilayah $(p>0,05)$. Jika dibandingkan dengan survei di Singapura menunjukkan sumber utama cairan tubuh adalah air putih (74\%), kemudian minuman teh dan kopi urutan kedua 32 persen, dan minuman ringan 17 persen. ${ }^{2}$ Pada siswa SMA, asupan susu rata-rata sebesar $172 \mathrm{ml}$ dan air teh 150 $\mathrm{ml} .^{8}$

Ternyata kontribusi asupan cairan yang berasal dari susu dan yogurt cukup signifikan $(5,3 \%)$, yaitu rata-rata per hari sebesar $156 \mathrm{ml}$ di wilayah pantai dan $109 \mathrm{ml}$ di wilayah pegunungan $(p<0,05)$. Asupan susu/yogurt tersebut jumlahnya sekitar 50 persen dibandingkan dari asupan negara maju. Survei di US menunjukkan asupan cairan (fluid) ke dalam tubuh sebesar $1764 \mathrm{ml}$ per hari, dengan rincian air putih $673 \mathrm{ml}$, susu $312 \mathrm{ml}$, teh dan kopi $360 \mathrm{ml}$, dan minuman ringan $420 \mathrm{ml}$ per hari. $^{7}$

\section{SIMPULAN}

Sebagian besar remaja di wilayah pegunungan $(73,2 \%)$ dan di wilayah pantai 52,3 persen lebih sering dan lebih banyak minum dari air minum tanpa kemasan. Alasan keamanan air minum menjadi pertimbangan utama remaja yang minum dari minuman kemasan atau tanpa kemasan. Teh dan kopi merupakan jenis minuman yang disukai di kedua wilayah, karena cita-rasa minuman untuk dikonsumsi selain air (plain water). Frekuensi minum air teh/kopi di kedua wilayah tidak berbeda.

Total asupan cairan dari aneka jenis minuman lebih tinggi di wilayah pantai (2787 ml) dibandingkan dengan di wilayah pegunungan $(2196 \mathrm{ml})$. Kontribusi terbesar asupan cairan tersebut berasal dari air minum, yaitu berturutturut 74,3 persen dan 67,9 persen.

\section{RUJUKAN}

1. Sawka MN, Cheuvront SN, Carter C. Human water needs. Nutr Rev 2005, (63)6: S30-S39.

2. AFIC [Asian Food Information Centre]. Fluid the forgotten factor. Singapore, Issues 9, October 2002.

3. Grandjean AC, Reimers KJ, Haven MC, Kurtis GL. The effect on hydration of two diets, one with and one without plain water. Jour of Am Coll of Nutr 2003, (22) 2: 165173.

4. Institute of Medicine. Dietary reference intakes for water, potassium, sodium, chloride, and sulfate. S.I: National Academic Press, 2004.

5. World Health Organization. Nutrients in drinking water. Geneva: WHO, 2005.

6. Departemen Kesehatan. Pedoman Umum Gizi Seimbang (PUGS). Jakarta: Depkes, 2005. 
7. Kleiner S. Water: an essential but overlooked nutrient. Jour of Am Diet Ass 1999, 99(2): 200-206.
8. Briawan D, Sedayu TR, Ekayanti I. Kebiasaan minum dan asupan cairan remaja di perkotaan. Jurnal Gizi Klinik Indonesia 2001, 8(1):36-41. 